\title{
APROXIMACIÓN AL ESTUDIO DE UNA MINORÍ ÉTNICA: INDIOS EN LA ESPAÑA DEL SIGLO XVI
}

\author{
por \\ ESTEBAN MIRA CABALLOS \\ Instituto de E. S. Zurbarán. Badajoz
}

RESUMEN: Este trabajo constituye una novedosa aproximación a una minoría étnica que prácticamente no ha sido estudiada por la historiografia moderna y contemporínea. Se trata de los indigenas americanos que llegaron a la peninsula, de manera más o menos forzada, a lo largo del siglo xvI y que en su mayor parte fueron vendidos en los mercados esclavistas peninsulares.

En este estudio analizamos la visión que los españoles tuvieron de esta minoría, el drama diario en la península de muchos de ellos, $y$, su integración en la cultura y la sociedad española, así como su conversión al catolicismo.

Palabras clave. España. Fistoria siglo xvi Indios, esclavitud, etnia, minoría social.

ABSTRACT: This study constitutes a novel approach to an ethnic minority that has never been studied by modern or contemporary historiography. It deals with American indians that were brought to Spain more o less forcibly along the $x v i t h$ century and for the most part were sold in peninsular slave markets. In this study it is analized the Spanish vision on this minority, their daily bearing in Spain, their integration in Spanish society and culture, as well as their conversion to the Catholic faith.

KEY WORDS: Spain. History xv th century. Indians, Slave. Ethnic minority.

\section{INTRODUcción}

Ante todo debemos decir que es bastante reducida la bibliografía con la que contamos para analizar la vida de los indios arribados a la Península en las primeras décadas del siglo xvi. Entre las obras que podemos citar se encuentra, en primer lugar, el trabajo de Alfonso Franco Silva ', ensayo elaborado con mate-

I FRANCo Suva, Alfonso: «El indigena en el mercado de esclavos de Sevilla(1500-1525)». Revista Gades, núm. 1, Cádiz, 1978, (págs. 25-35). 
riales procedentes del Archivo de Protocolos de Sevilla y de gran interés, pues, constituye el primer estudio monográfico sobre los indios americanos llegados tras el Descubrimiento, y, por tanto, es pionero en este campo de investigación.

En segundo lugar, haremos referencia a dos comunicaciones presentadas por Juana Gil-Bermejo y publicadas en 1983 y 1990 respectivamente ${ }^{2}$. En esta ocasión, la autora utilizó las fuentes procedentes del Archivo General de Indias, y, más concretamente, unos pleitos de la sección de Justicia. Y en tercer, y último, lugar, nos referiremos a un trabajo nuestro en el que aportamos nuevas líneas de investigación sobre esta temática ${ }^{3}$.

Como es bien sabido en los primeros años se produjo una política dubitativa que favoreció la traída de indios esclavos a Castilla ${ }^{4}$. Así, y como es de sobra conocido, ya Cristóbal Colón al retornar de su primer viaje llevó consigo varios indios a Castilla, siendo aceptado tácitamente este tráfico por los propios Reyes Católicos al ordenar que se vendiesen en Andalucía. Poco tiempo después, y más concretamente en 1500, los propios Monarcas debieron recapacitar ya que dispusieron que se pusiesen en libertad y se devolviesen a sus lugares de origen en el Continente americano ${ }^{5}$. Sin embargo, está ley se mostró poco duradera, pues, nuevamente en 1503, se autorizó de nuevo su traída a Castilla con la única condición de que fuese voluntariamente aceptada por los propios indígenas ${ }^{6}$.

Esta orden real de 1503 supuso la reanudación de todo el tráfico de indios americanos a Castilla. Además, las condiciones no se cumplieron, pues, se embarcaban sin la requerida autorización del gobernador y con informaciones falsas sobre su supuesta venida voluntaria. En este sentido, conocemos una auténtica colección de reales cédulas que, desde 1512, repitieron sin cesar la prohibición de la trata de indios esclavos ${ }^{7}$. El hecho de que constantemente

2 Gil-Bermejo García, Juana: «Indígenas americanos en Andalucía». Andalucía y América en el siglo XV. Sevilla, E.E.H.A., 1983, (págs. 535-555). "Ideas sobre el indio americano en la España del siglo XVIr. La imagen del indio en la Eumopa Moderna. Sevilla, E.E.H.A., 1990, (págs. 117-125).

${ }_{3}$ Mira Caballos, Esteban: "Indios americanos en Castilla (1492-1550)", Actas del X Congreso Internacional de AHILA, Leipzig, 1993, (en prensa).

4 A este respecto puede verse la obra de RUMEU DE ARMAS, Antonio: La política indigenista de Isabel la Católica. Valladolid, Instituto Isabel la Católica, 1969, págs. 127 y ss.

5 Mira Caballos; ob. cit.

6 Ibidem.

7 Esta prohibición se establece en 1512 y se ratifica en 1528 , en 1531 , en 1533 , en 1536, en 1538, en 1543, en 1547, en 154 y en 1549. Real Cédula a Diego Colón, Burgos, 12-VIIl+1512. AGl, Indiferente General 419, L. 4, ff. 9-9v. Real Cédula a los oficiales de la Casa de la Contratación, 4XII-1528. Recopilación de Leyes de Indias de 1680, T. I, L. VI, Tit. I, leg. 16. Real Cédula a los oficiales de la Casa de la Contratación, Medina del Campo, 15-XII-1531. AGI, indiferente General 1961, L. 2, f. 114. Real Cédula a los oficiales de la Casa de la Contratación, Madrid, 3-II-1533. AGI, Indiferente General 1961, L. 3, f. 109v. Real Cédula a los oficiales de la Casa de la Contratación, Madrid, 14-I-1536. AGI, Indiferente General 1962, L. 4, ff. 27-27v. Real Cédula a la Audiencia de Santo Domingo, Valladolid 14-VIl-1543. AGI, Santo Domingo 868, L. 2, ff. 197v-189. Real Cédula a los of iciales de la Casa de la Contratación, Valladolid 9-VII-1548. AGI, Indiferente General 1964, L. 11, f 8v. Real Cédula a los oficiales de la Casa de la Contratación, Valladolide, 1-V-1549. AGI, Indiferente General 1964, L. 11, ff. 226-226v.

Hispania. LVI/3, núm. 194 (1996) 945-964 
se recuerde tal prohibición nos está indicando claramente que no se cumplía, pues, además en todos estos documentos se reconoce que se habian llevado multitud de ellos a vender «escondidamente» a la Península Ibérica.

Más concretamente en un una Real Cédula, fechada en 1534 y dirigida a los oficiales de la Casa de la Contratación se denunciaba el gran número de indios esclavos que había ilícitamente en Sevilla. Dado el interés del documento lo reproducimos parcialmente en las líneas que vienen a continuación:

«Por parte de Juan de Cárdenas me ha sido hecha relación en este Consejo que en Sevilla hay muchos indios naturales de la Nueva España y de otras partes de las Indias los cuales siendo libres los tienen por cautivos y siervos. Que nose vendan ni hierren porque sabemos que los que los traen los hierran en el rostro o les echan argollas de hierro a la garganta con letras de sus propios nombres en que dicen ser sus esclavos..." 8 .

Por lo demás, y pese a la terminante prohibición impuesta sobre la esclavitud del indio en las Leyes Nuevas de 1542, sabemos que no se respetó, continuándose con la trata indígena durante décadas ${ }^{9}$. Así, tenemos registrado el embarque para la Península, tan sólo en el periodo comprendido entre 1492 y 1550, de cerca de 2.000 aborigenes, siendo su destino principal abastecer el mercado esclavista ${ }^{10}$. No obstante, gracias al empeño de la Corona por erradicar la trata indígena se evitó, en palabras de Domínguez Ortíz, que las colonias indianas se convirtieran «en un inmenso mercado de aprovisionamiento de esclavos para la metrópoli...»"

\section{LOS MOMENTOS INICLALES EN LA PENINSULA}

Una vez en tierras españolas, lo primero que se hacía con los supervivientes era bautizarlos, tanto si se trataba de indios libres como si por contra eran esclavos, cambiándoles su nombre original por uno católico, frecuentemente el de su amo o propietario ${ }^{12}$. Así, ya los indios que llevó Cristóbal Colón a la corte de los Reyes Católicos, en 1493, fueron bautizados de manera pintoresca según nos consta por la descripción que hizo el cronista Gonzalo Fernández de Oviedo:

8 Real Cédula a los oficiales de la Casa de la Contratación, Dueñas, 25 de septiembre de 1534. AGI, Indiferente General 1961, L. 3, ff. 15lv-152.

9 Sin duda, esta situación se vio favorecida por la falta de una política firme en torno a esta cuestión, fomentándose desde la Corona la introducción en Castilla tanto de mestizos como de hijos de caciques to cual constituian excepciones a la regla generat que creaban un clima de confusión propicio al fraude.

to MiRa Caballos: ob. cit.

11 Dominguez Ortiz, Antonio: Orto y ocaso de Sevilla. Sevilla, Publicaciones de la Universidad de Sevilla, 1991, pág. 102.

12 Concretamente conocemos el caso de una india que declaró que al llegar a España se le puso por nombre Catalina pues también «su ama se llamaba Catalina». Pleito por la libertad de la india Catalina esclava de Juan Pontiel de Salinas, vecino de Madrid, I552. AG], Justicia 1021, N. 3, R. I. 
"Y ellos de su propia voluntad y consejados, pidieron el bautismo; y los Católicos Reyes, por su clemencia, se lo mandaron dar; y juntamente con sus Altezas, el serenísimo príncipe don Juan, su primogénito y heredero, fueron padrinos. Y a un indio que era el más principal de ellos, llamaron don Fernando de Aragón, el cual era natural de esta isla Española y pariente del Rey o cacique Goacanagarí; y otrollamaron don Juan de Castilla; y los demás se ledieron otros nombres, como ellos los pidieron o sus padrinos acordaron que se les diese conformea la iglesia católica» ${ }^{13}$.

Sin duda, este suceso relatado por Fernández de Oviedo era en cierta medida excepcional al tratarse de los primeros habitantes del Nuevo Mundo que pisaban tierra europea, siendo además apadrinados por los propios Reyes. Sin embargo, como es lógico lo normal fue que el indígena se bautizase como un cristiano más y se inscribiera sin diferencia alguna en los registros de bautismo de las parroquias de aquellas ciudades a las que llegaban ${ }^{14}$. En concreto, se sabe de la existencia en el Archivo de Guadalupe de dos partidas de bautismo de otros de los indios que trajo a España el primer Almirante y que por su importancia transcribimos a continuación:

"Viernes XXIX de este dicho mes, se bautizaron Cristóbal y Pedro, criados del señor Almirante don Cristóbal Colón. Fueron sus padrinos, de Cristóbal Antonio de Torres y Andrés Blázquez. De Pedro fueron padrinos el señor Coronel y Señor Comendador Varela, y Bautizolos Lorenzo Fernández, capellán” "15.

Ya el viaje resultaba sumamente dramático para estos indios pues, según se refleja en la documentación de la época, eran seres que «con poca diferencia que se les hacía lo sentían mucho" ${ }^{16}$. Sin embargo no era mejor el futuro que esperaba a aquellos que lograban sobrevivir a la travesía, siendo especialmente difíciles los primeros días ya que, por un lado, los aborígenes llegaban muy debilitados, y por el otro, se debían adaptar a una sociedad y a una forma de vida muy diferente a la que habían dejado en sus regiones de origen. Por todo ello el índice de mortalidad indígena durante los primeros meses en la península debió ser muy elevado.

13 Fernandez De Oviedo, Gonzalo: Historia General y Natural de las Indias. Madrid, Ed. Atlas, 1992, T. I, Cap. VII, pág. 31.

14 Por desgracia, se han conservado muy pocos libros sacramentales de estas fechas, pues, como es bien sabido, no fue obligatorio tenerlos en las parroquias hasta después del Concilio de Trento. En cualquier caso en la actualidad estamos trabajando en algunos de estos libros Sacramentales del siglo XVI, extrayendo los indios a los que se les administraron los Santos Sacramentos.

is Garcta, Sebastián O. F. M.: Guadalupe de Extremadura en América. Madrid, Gráficas Don Bosco, 1991, pág. 67. Veinte días después se bautizó otro indio llamado Jerónimo. También en V.V.A.A.: Los Franciscanos y el Nuevo Mundo. Sevilla, Ediciones Guadalquivir, 1992, págs. 38-39

16. De ahi que la Corona insistiese en que se controlase su traslado a la Península "porqque con la mudanza que hacen de la tierra en viniendo acá (a Castilla) se mueren de que nos somos deservidoss. Real Cédula a los oidores de La Española, Granada 26 de octubre de 1526. AGI, Indiferente General 421, L. 11, ff, 264v-267. Real Cédula al gobernador o juez de residencia de Puerto Rico, 26 de octubre de 1526. AGI, Indiferente Generaj 421, L. 11, ff. 267-270v.

Hispania. LVi/3, núm. 194 (1996) 945-964 
Así, en España, además de que los alimentos le faltaban, se solían poner muy enfermos, debido a lo que los demógrafos suelen denominar el "choque epidemiológico». Las perspectivas de supervivencia en el Reino de Castilla no eran desde luego nada halagüeñas como se puede deducir del texto, fechado en 1543, que exponemos a continuación:

«Somos informados que los españoles y personas que residen en las dichas nuestras Indias, cuando vienen de elias a estos Reinos traen con ellos muchos indios e indias naturales de esas partes...Y se ha visto por experiencia que antes que lleguen a estos Reinos y después de llegados a ellos por ser diferente la calidad de las partes por donde pasan y de estos Reinos a sus naturalezas y ser ellos de flaca complexión y demás de esto salidos de poder de las personas que los traen se pierden por no tener industria de ganar de comer en esas partes..." ${ }^{17}$.

Así, por ejemplo sabemos que a fines de 1516 arribaron al puerto de Valencia 85 indios brasileños, falleciendo en breve tiempo nada menos que $23^{18}$. Igualmente, en 1543 un tal Ginés de Carrión «El Viejo» declaró haber traído de las Indias seis aborígenes, herrados en Venezuela y comprados por él en Santo Domingo, de los cuales se le habían muerto todos salvo dos indias, una de las cuales se encontraba enferma y "metida de pescuezo algo corcobada" 19. Asimismo, conocemos el caso de ciertos indios que se depositaron, en 1544, en un tal Pero Almíndez, otorgándosele para su mantenimiento cien ducados, que los tuvo que devolver de inmediato porque en breve tiempo se le murieron ${ }^{20}$. Y finalmente citaremos el caso de tres indios y una india depositados en el Obispo de Lugo de los cuales en pocos meses fallecieron los tres primeros, mientras que la mujer india, que se llamaba Isabel, estuvo mucho tiempo "tullida en una cama" hasta que falleció ${ }^{21}$. Creemos que los casos citados son lo suficientemente representativos para demostrar la alta mortalidad que sufrieron estos aborígenes en los primeros momentos de la llegada a España.

\section{EL STATUS SOCIAL DEL INDIO Y SU INTEGRACION EN LA SOCIEDAD ESPAÑOLA}

Para el análisis de la visión que los españoles tuvieron del indio debemos recurrir, como bien afirmó Juana Gil-Bermejo, a una fuente básica como son las crónicas indianas ${ }^{22}$.

17 Real Cédula a los oidores de Santo Domingo, Valladolid 28 de septiembre de 1543. AGI, Indiferente general 423, L. 20, ff, 698-700.

18 CorTés Alonso, Vicenta: La esclavitud en Valencia durante el reinado de los Reyes Católi$\cos$ (1479-1516). Valencia, Excmo. Ayuntamiento de Valencia, 1964, pág. 60.

19 Pleito por la libertad de las indias de Ginés de Carrión, 1543. AG1, Justicia 741, N. 3.

${ }^{20}$ Real Cédula a los oficiales de la Casa de la Contratación, Valladolid, 29 de agosto de 1544. AGl, Indiferente general 1963, L. 9, ff. 110-1 10v.

21 El obispo solicitó por ello una compensación económica por las medicinas y alimentos especiales que les proporcionó, especialmente a la mujer india. Real Cédula a los oficiales de la Casa de la Contratación, Tałavera, 26 de julio de 1541. AGI, Indiferente general 1963, L. 8, ff. 36v-37v.

22 GiL-BerMejo: El indio, ob. cit., pág. 123 
En un primer momento, ante la sincera amistad entablada por los españoles las descripciones sobre los indígenas fueron bastante benévolas. Además, los hispanos mostraron su encanto por estos seres exóticamente pintados y vestidos, siendo una buena muestra de ello las bellas descripciones que, tanto el propio Almirante Cristóbal Colón como el cronista Pedro Mártir de Anglería, escribieron del aborigen. Concretamente este último lo describió así:

"Veo que nuestros isleños de la Española son más felices que aquellos, siempre que reciban la doctrina cristiana, ya que pasan su existencia desnudos, libres de pesos y medidas y del mortífero dinero, viviendo en la Edad de Oro, sin leyes, ni jueces calumniosos, sin libros, contentos con suestado natural, sin preocuparse en absoluto por el futuro: con todo, también éstos se ven atormentados por la ambición por el poder y se hostigan mutuamente con guerras, peste de la que no creemos que viviera durante la Edad de Oro.... ${ }^{23}$.

Asimismo la primera descripción que tenemos de indios en España nos la dejó Andrés Navajero quien al visitar Sevilla entre 1526 y 1528 una de las cosas que mas le llamó la atención fue unos indios «jugando con una pelota». En sus palabras se pone de manifiesto la admiración que debieron causar en este lado del océano estos indios, de rasgos tan característicos, que acompañaban a los españoles recién llegados del Nuevo Mundo. Dado el interés del texto lo reproducimos en las líneas que siguen:

«...También vi algunos jóvenes de aquellas tierras (se refiere a las Indias) que acompañaban a un fraile que había estado allí predicando para reformar las costumbres de los naturales y eran hijos de señores de aquellos países; iban vestidos a su usanza,medio desnudos, y sólo con una especie de juboncillo oenagüetas; tenían el cabello negro, la cara ancha, la nariz roma, casi como los circasios, pero el color tira más a ceniciento; mostraban tener buen ingenio y vivo para todo, pero lo singular era un juego de pelota que hacían a estilo de su tierra: la pelota era de una especie de leño muy ligero y que botaba mucho, tamaño como un melocotón o mayor, y no la rebatían con las manos ni con los pies, sino con los costados, lo que hacian con tal destreza que causaba maravilla verlo; aveces se tendsan casi en tierra para rebatir la pelota, y todo lo hacían con gran presteza» ${ }^{24}$.

Sin embargo, los propios descubridores no tardaron en darse cuenta que el principal recurso de aquellas islas no era la tierra, ni tan siquiera el oro, sino la mano de obra aborigen ${ }^{25}$. Así, aprovechando el quebrantamiento de la

${ }^{23}$ Citado en Gil, Juan y Varela, Consuelo : Cartas de particulares a Colón y Relaciones coetáneas, Madrid, Alianza Universidad, 1984, pág. 58.

${ }^{24}$ NAVAGERo, Andrés: Viaje por España (1524-1526), Madrid, Editorial Túrner, 1983, págs. 4041 y 124-125. También citado en MonToto, Santiago: Biografía de Sevilla. Sevilla, Editorial Castillejo, 1990, pág. 213. El juego que describe Navagero estaba muy difundido en América y se practicaba en extensas zonas de Mesoamérica y en el área antillana.

${ }^{25}$ Véase por ejemplo la obra de ARranz Marquez, Luis: Repartimientos encomiendas en la isla Española(El Repartimiento de Alburquerque de 1514). Madrid, Fundación García Arévalo, 1991, pág. 26.

Hispania, LV1/3, núm. 194 (1996) 945-964 
paz por parte de los indígenas los españoles comenzaron un ataque violento sobre los naturales, surgiendo como contrapartida una dura resistencia -no siempre de carácter bélica- de estos últimos. La nueva situación se detecta perfectamente en los relatos de los cronistas en los que la descripción del indio cambió por completo, de manera que esos idílicos seres "bien hechos" de que nos hablaba el propio Cristóbal Colón fueron presentados en poco tiempo de manera muy diferente, es decir, como seres inferiores, viciosos, ladrones, holgazanes, etc. Son calificativos que aparecen reiteradamente tanto en las crónicas como en la documentación de la época. Los españoles, pues, los consideraron finalmente como seres racionales pero inferiores, sin conciencia y volubles en su pensamiento ${ }^{26}$.

Esta visión sesgada de la realidad llegó a España con tanta fuerza que, incluso, en muchos de los pleitos por la libertad de los indígenas los españoles declararon que éstos eran personas "de muy poco trabajo» y "ladrones". Lógicamente se trata de opiniones muy subjetivas que no debemos valorar como ciertas, pues, como es de sobra conocido, este tipo de calificativos fueron frecuentemente utilizados no sólo contra los indígenas sino contra todos los sectores sociales marginados y muy en particular contra los esclavos negros. Tan sólo en algunas ocasiones se menciona en los pleitos su condición de "servidores más leales» que los esclavos negros ${ }^{27}$ aunque es posible que está idea se sustentase tan sólo en el hecho de la mayor ingenuidad de los indios en relación a los negros, incapaces muchos de ellos de reivindicar sus propios derechos, y cuando lo hacían, era siempre después de largas décadas de aprendizaje en la Península.

Por ello sobre los indios se vertieron las discriminaciones comúnmente aplicadas a otras minorías, no permitiéndoseles ocupar cargos públicos ni por supuesto acceder al orden sacerdotal, pues se consideraba que no eran seres dignos para el desempeño de tales funciones ${ }^{28}$.

Pese a todo tenemos constancia documental de la existencia de indios desempeñando oficios artesanales o de servicios que requerian una cierta especialización, tales como carpintería, sastrerfa o cocina. Así, en uno de los numerosos pleitos que se generaron por la libertad de estos indígenas, los testigos declararon que un indio llamado Francisco Manuel «habia servido cuatro años y más tiempo muy bien y fielmente haciendo todo lo que le ha mandado así de noche como de día así en su oficio de carpintero como en

26 A este respecto puede verse mi trabajo: «El pleito Diego Colón-Francisco de Solis: el primer proceso por malos tratos a los indios en La Española(1509).. Anuario de Estudios Americanos, T. L, N. 2, Sevilla, 1993, págs. 314-317.

27 Así, por citar un ejemplo concreto, en un pleito, despachado a mediados del siglo XVI, sobre la libertad de un indio, llamado Francisco, propiedad de un vecino de Almendralejo (Badajoz), el testigo Guido de Lavacares dijo: «que este testigo sabe que estos indios son grandes servidores y de confianza y diligencia por lo que merecen mucho...,. Pleito entre el indio Francisco y Juan Ortiz Corrales, 1556. AGI, Justicia 1022, N. 4, R. l. Otro de los testigos, un tal Pedro Ortiz de Zúñiga, manifestó en la misma linea que Guido de Lavacares que «estos indios son grandes serviciales». Ibidem.

28 GIL-BERMEro: Los indios, ob. cit., pág. 120. 
todas las otras cosas que le ha mandado el dicho Sebastián de Aguilar y su mujer y madre.... ${ }^{29}$.

Igualmente, conocemos la existencia de un indígena, llamado Juan Díaz, natural de Cubagua, y que vivía en Sevilla, en concreto en la Puerta de Jerez donde tenía instalado su propio taller de sastrería desde la década de los cuarenta ${ }^{30}$. Asimismo, otro indio, llamado Juan, se ganaba la vida trabajando a jornal como tundidor en la villa de Baeza ${ }^{31}$.

También en Almendralejo (Badajoz) sabemos que vivió un indio esclavo, llamado Francisco, del que se decía en 1556 que era «trabajador y va al campo a cavar y a arar en esta villa y que es muy diligente en su manera porque después que le conoce en esta villa le ha visto siempre ir a trabajar y a ganar su jornal como los otros que andan al dicho oficion y que por ello merecía 12 ducados por cada año trabajado ${ }^{32}$.

Finalmente, mencionaremos el caso de un aborigen que sirvió, durante largos años, a un canónigo de la catedral de Toledo como "oficial de cocinero» 33. Este indio, llamado Cristóbal, había aprendido el oficio, durante sus primeros años de estancia en casa del canónigo Diego López de Ayala "con un cocinero que tenía que se llamaba Madrid...» ${ }^{34}$. En el pleito entablado con la heredera del citado religioso, doña Isabel de Finolete, el indio Cristóbal solicitó por el trabajo que había prestado nada menos que 10.000 maravedís anuales cifra sin duda muy elevada. La defensa que hizo la heredera del canónigo para no pagar dicha cantidad no incidió en el hecho de que no fuera buen cocinero que quedó claro que sí lo era, sino que en la cocina «bebía demasiado y para jugar y dar a mujeres de que era vicioso hurtaba todo lo que podía y hallaba en la despensa" ${ }^{35}$. De nuevo en esta ocasion se acusó a un indio de ladrón y borracho con el único fin de desacreditarlo. En realidad, uno de los testigos aportó un testimonio sumamente revelador al afirmar que a la mujer que más le daba era a una que se llamaba María de Mena que «el dicho esclavo dijo a este testigo que se había casado con ellas ${ }^{36}$, lo cual nos confirma que si bien era cierto que robaba alimentos lo hacía para abastecer a su propia mujer.

La cualificación y el nivel profesional de estos indígenas se pone de manifiesto cuando en las sentencias se condenaban a pagar a muchos antiguos propietarios nada menos que 10 o 12 ducados de indemnización por cada uno

29 Pleito entre el indio Francisco Manuel y Catalina Gil, 1553. AGI, Justicia 1022, N. 1, R. 2.

30 Este indio fue presentado por testigo en el pleito entre el carmonense Juan Cansino y el fiscal del Consejo de Indias por la libertad de varias indias. Se declaró así mismo como vecino de la puerta de Jerez y natural de la isla de Cubagua. AGI, Justicia 908, N. 1.

31 Pleito por la libertad del indio Esteban, 1553-1558. AGI, Justicia 1023, N. 1, R. 1.

32 Pleito entre el indio Francisco y Juan Ortiz, 1556. AGI, Justicia 1022, N. 4, R. 1, ff. 53-53v.

33 Pleito entre Cristóbal, indio, y doña Isabel de Finolete, Toledo, 1561. AG1, Justicia 1013, N. 2, R. 4.

34 Ibidem.

35 Ibidem.

36 Ibidem. Respuesta del testigo Diego de Ayala a la pregunta sexta.

Hispania, LV1/3, nủm. 194 (1996) 945-964 
de los años servidos y en algunas ocasiones mucho más. Así le ocurrió, por ejemplo, a la viuda de Hipólito Sedano, vecina de la villa de Monzón, que hubo de pagar 12 ducados por cada uno de los 14 años de servicio prestado por un indio suyo llamado Gonzalo ${ }^{37}$.

Pese a todo no podemos perder de vista que se trataba, en aquella época, de oficios serviles que en absoluto elevaban el status social de quienes lo desempeñaban. No en vano, ha escrito Morales Padrón, que muchos de los esclavos de la Sevilla del Quinientos fueron cocineros, olleros, albañiles, curtidores y criados ${ }^{38}$, es decir, desempeñaron justo los mismos oficios que los indios afincados en Castilla, según hemos visto en las líneas precedentes. No debemos olvidar que en el siglo xvi el $80 \%$ de la población vivía en una pobreza más o menos aguda y que tanto los artesanos como los pequeños mercaderes eran grupos poco prestigiosos socialmente ${ }^{39}$.

Además, otros aborígenes desempeñaron incluso oficios de menor cualificación, siendo su indemnización anual por cada año que sirvieron de tan sólo 5 ducados ${ }^{40}$. Se trataba en estos últimos casos de indígenas que servían como simples mozos y recaderos, pues no habían aprendido otras habilidades.

Por otro lado, otros indios tras ser liberados, después de los juicios, terminaban como mendigos en las calles de las principales ciudades españolas por lo que Su Majestad acabó por concederles pasaje gratuito a sus regiones de origen en el continente americano a todos aquellos que estuviesen en esta situación ${ }^{41}$.Concretamente, sabemos que en Triana vivía un indio ciego que sobrevivia de las limosnas que obtenía mendigando por las calles ${ }^{42}$. Estos desdichados seres engrosaron la larga lista de mendigos y miserables que proliferaron en Sevilla a la sombra de las opulencias que paradójicamente generó el Nuevo Mundo.

No obstante, e independientemente de su ocupación profesional, la mayoría de estos indios se integraron plenamente en la sociedad española, aprendiendo la lengua castellana y practicando la religión católica. Dado que una de las constantes de estos indios es que habian sido traf́os a España con poca edad, frecuentemente entre los ocho y los doce años, lo normal era que en un

37 Pleito sobre la libertad del indio Gonzalo, 1554. AGI, Justicia 1022, N. 2, R. 3. La misma sentencia recayó sobre Catalina Alonso, vecina de Cortegana, mujer de Alonso Romero que hubo de pagar dicha cantidad anual a un indio que le servía llamado Díego. Pleito sobre la libertad del indio Diego, 1553. AGI, Justicia 1022, N. 1, R. 5.

38 MoRales Padrón, Francisco: La ciudad del Quinientos, T. IV de la Historia de Sevilla. Sevilla, Secretariado de Publicaciones de la Universidad de Sevilla, 1977, pág. 103.

39 Morell. Peguero, Blanca: Mercaderes y artesanos en la Sevilla del Descubrimiento. SeviHa, Excma. Diputación Provincial, 1986, págs. 140-143.

40 Pleito por la libertad de un indio llamado Diego de doña Inés Carrillo, 1534. AGl, Justicia 716, N. 4.

41 Real Cédula a los jueces de la Casa de la Contratación, Valladolid 15 de noviembre de 1552. Recopilación de Leyes de Indias, T. II, Lib. VI, Tit. l, Ley XVII.

42 Pleito por la libertad de la india Beatriz esclava de Juan Cansino, 1558. AGI, Justicia 908, N. 2. 
breve espacio de tiempo olvidaran su idioma originario para adoptar plenamente el castellano. Así, por ejemplo, la india Magdalena, natural de la Nueva España, declaró que entendía el idioma Nahuatl pero que, sin embargo, no hablaba más que castellano ${ }^{43}$. De la misma forma, uno de los testigos del pleito sobre la libertad de un indígena llamado Francisco Manuel, en 1553, declaró lo siguiente:

"Que el dicho Francisco indio es natural de Nueva España porque este testigo ha estado mucho tiempo en ella y en la fisonomía del rostro parece a los indios de la provincia y este testigo le habló en lengua mexicana qué de que tierra era y el dicho indio respondió, en español, que era de Colima y que no sabía hablar la lengua aunque la entendía por haber mucho tiempo que salió de la dicha provincia de la Nueva España y cuando vino de ella era niño» ${ }^{44}$.

En este mismo sentido citaremos el caso de la india Magdalena que era esclava de un vecino de Valladolid a la "que se le preguntó en lengua mexica que de donde era y respondió en castellano que de Nueva Españan, lo cual nos parece sumamente sintomático del total aprendizaje de la lengua castellana ${ }^{45}$.

Estos aborígenes además de conocer perfectamente la lengua castellana cumplían con todos los Sacramentos católicos, confesando y comulgando cuando mandaba la Iglesia. En este sentido, en el pleito por la libertad de los indios del escribano Pedro de Castellanos se demostró que a sus dos indias las instruyó en la fe "haciéndoles confesar y comulgar en el tiempo que manda la Santa Madre Iglesia” ${ }^{46}$. Igualmente conocemos el caso de un indio llamado Juan de Oliveros, que tras ser declarado libre, en 1549, se desposó en la iglesia de Santa Ana de Sevilla, con una india trianera llamada Inés ${ }^{47}$.

En definitiva, la visión que se ofrece en las fuentes es que algunos de estos indios llegados del Nuevo Mundo aprendieron ciertos oficios propios del grupo pechero integrándose en la sociedad española. No obstante su trato y su situación socio-laboral no se diferenció en absoluto de la que disfrutaban los esclavos negros. Otros, incluso, corrieron peor suerte, engrosando las grandes partidas de mendicidad, que tan comunes fueron en las principales ciudades y villas españolas del Antiguo Régimen.

43 Pleito sobre la libertad de la india Magdalena, propiedad de Santiago de San Pedro, vecino de Valladolid, 1554. AGI, Justicia 1022, N. 2, R. 2.

44 Pleito entre el indio Francisco Manuel y Catalina Gil, 1553, octava pregunta. AGI, Justicia 1022, N. 1, R. 2.

45 Pleito sobre la libertad de la india Magdalena, 1554. AGl, Justicia 1022, N. 2, R. 2.

46 Pleito por la libertad de los indios del escribano Pedro Castellanos, 1549. AGI, Justicia 758, N. 4.

47 En el pleito por la libertad de Juan de Oliveros un testigo indio llamado Juan García declaró que estuvo presente cuando se desposó éste con la india Inés en la iglesia de Santa Ana de Triana y que la india era de un vecino de Triana llamado Blas Gallego. Pleito por la libertad de Juan de Oliveros y Beatriz, indios. AGI, Justicia 757, N. 3 .

Hispania, LVV/3, nủm. 194 (1996) 945-964 


\title{
III. LOS MERCADOS DE ESCLAVOS INDIGENAS
}

Una vez bautizados la pretensión principal era venderlos a buen precio en algún mercado esclavista, o bien, servirse directamente de ellos, utilizándolos como pajes ${ }^{48}$ en el caso de ser varones, o públicamente como concubinas en el caso de ser mujeres, lo cual conllevaba, como es sabido, un gran prestigio social para su poseedor o dueño. En relación a esta última circunstancia, es decir, al concubinato con las mujeres antillanas, contamos con una Real Cédula, fechada en 1536, en la que esta situación queda perfectamente demostrada:

\begin{abstract}
«Soy informado que algunos marineros y pasajeros y otras personas que vienen de Indias traen consigo algunas mujeres indias por esclavas y otras libres con las cuales, en ofensa de nuestra conciencia, y no miran en su instrucción en la fe y tienen acceso carnal y las retienen en sus casas continuando su pecado, por ello, mando que cuando vengan navíos os informéis si van o vienen algunas mujeres indias libres o esclavas y ved si tienen acceso carnal. Si son esclavas que la vendan en pública almoneda en unos días y si fueran indias libres sacadlas de su poder y ponedlas en poder de mujeres honestas.... ${ }^{49}$.
\end{abstract}

Los indios eran adquiridos en las tradicionales ferias y mercados donde se acostumbraba a comprar los esclavos negros. Así, por ejemplo, el carmonense Silvestre de Monsalve declaró haber comprado a un portugués una india llamada Felipa en la feria de Zafra (Badajoz) "donde se vendían los esclavos» ${ }^{50}$.

Sin embargo, existieron dos grandes mercados de indios por antonomasia en donde los castellanos compraban y vendían a sus indios, situados en Sevilla y Lisboa. En relación al sevillano, podemos decir que era lógico si tenemos en cuenta que era el puerto de arribada de los navíos del Nuevo Mundo. De hecho, en la década de los cuarenta debió haber en esta capital más de 200 indios esclavos ${ }^{51}$.

Años después y más concretamente a partir de la década de los treinta, la legislación contra la introducción de aborígenes en la Península se tornó tan severa que el mercado de esclavos indios se desplazó a un segundo lugar, en

\footnotetext{
48 Carta de la Audiencia de Santo Domingo a Su Majestad, Santo Domingo, 27 de julio de 1549. en la cual le explica la utilización de aborígenes como pajes. AGI, Santo Domingo 49, R. 19, N. 122 BIS.

49 Real Cédula a los oficiales de la Casa de la Contratación, Madrid, 14 de enero de 1536. AGI, Indiferente General 1963, L. 4, ff. 27-27v.

30 Pleito entre el fiscal del Consejo de Indias y Silvestre de Monsalve por la libertad de la india Bárbola, hija de Felipa difunta, 1559-1564. AGI, Justicia 783, N. 3. Más información sobre este pleito en AGI, Patronato 287, 288 y 289.

51 En la década de los cuarenta el Rey ordenó hacer un libro en el gue se asentasen todos los indios esclavos que había en Sevilla. Por desgracia, no hemos localizado dicho libro aunque en los ya citados pleitos por la libertad de los indios se hace alusión a él frecuentemente. Sin embargo, todo parece indicar por algunas referencias de testigos que su número era superior a 200.
} 
concreto, a la capital del vecino reino portugués, es decir, a Lisboa. A esta ciudad lusitana llegaron, pues, tanto los indios procedentes del Brasil —donde no estaba prohibido su cautiverio ${ }^{52}-$ como de las propias Indias Españolas. Desde los mercados esclavistas de las Antillas y de la Nueva España los traficantes llevaron estos indios directamente a Portugal, para a continuación venderlos como si fuesen originarios de las colonias portuguesas ${ }^{53}$. En este sentido, en el pleito por la libertad de un indígena llamado Esteban, propiedad de un vecino de Baeza, se intentó demostrar que era del Brasil, basándose en el hecho de que fue comprado en Lisboa. No obstante, las investigaciones del fiscal del Consejo de Indias demostraron que, años antes, habia sido vendido en Lisboa por un marinero de Sanlúcar de Barrameda que lo había traído a su vez del virreinato de la Nueva España ${ }^{54}$.

Había, incluso, pequeños traficantes en muchas localidades españolas que se dedicaban a comprar indios en la capital lusitana para luego venderlos en distintas ciudades españolas. Este era el caso de un vecino de Baeza, llamado Alonso Sánchez Carretero, que fue a Lisboa a comprar 15 indios, pues tenfa por oficio "comprar y vender esclavos» 55 . Concretamente en el importante mercado de esclavos de Valencia sabemos, gracias al ya citado trabajo de Vicenta Cortés, que en 1509 se vendió un esclavo brasileño, mientras que a fines de 1516 llegaron para su venta otros 85 indios de la colonia portuguesa ${ }^{56}$

Por otro lado, muchos de estos aborígenes que llegaron sin marca alguna de esclavos a España fueron herrados en la cara en la propia península donde, según parece, el control sobre la utilización del hierro real era menos severo. En esta línea se expresaba el Rey en un escrito de 1534, dirigido a los oficiales de la Casa de la Contratación de Sevilla y en el que decía textualmente:

52 En todos los pleitos por la libertad de los indígenas los testigos españoles repitieron sin cesar la licencia que habia para cautivar indios de las regiones del Brasil. Por citar un ejemplo, expondremos la afirmación de un testigo flamenco, llamado Guillermo del Reno, en un pleito llevado a cabo en 1559:

«Dijo este testigo que sabe y es público y notorio a todos que los brasiles y sus tierras tienen conquista y guerra unas provincias contra otras y se matan y prenden y cautivan a otros y se comen por ser gente que vive sin fe y sin ley cristiana ni razón ni orden de vivir y los que no quieren comer los venden y rescatan a los portugueses en las provincias que en las dichas partes están de cristianos y todos los esclavos del Brasil que de allá vienen a este Reino todos son habidos por esclavos cautivos y por tales y como todos se sirven de ellos y los compran y venden públicamente...,\%. Pleito por la libertad de los indios de Francisco Bravo, vecino de Valladolid 1559. AGI, Justicia 1023, N. 2, R. 2.

53 A partir de la década de los cuarenta son multitud los casos que hemos localizado de indios que declararon haber sido vendidos en Lisboa pero que no eran originarios del Brasil sino del algún lugar de la Nueva España.

54 Pleito por la libertad del indio Esteban propiedad de Diaz Sánchez de Cabrera, vecino de Baeza, 1553-1558. AGI, Justicia 1023, N. 1, R. 1.

55 Pleito por la libertad del indio Esteban, propiedad de Diaz Sánchez de Cabrera, 1553-1558. AGI, Justicia 1023, N. 1, R. 1.

56 CORTĖs Alonso: ob. cit., pág. 60.

Hispania, LVL/3, núm. 194 (1996) 945-964 
"Por parte de Juan de Cárdenas me ha sido hecha relación en este Consejo que en Sevilla hay muchos indios naturales de la Nueva España y de otras partes de las Indias los cuales siendo libres los tienen por cautivos y siervos. Que nose vendan ni hierren porque sabemos que los que los traen los hierran en el rostro o les echan argollas de hierro a la garganta con letras de sus propios nombres en que dicen ser sus esclavos.... 57 .

Por otra parte, en el pleito por la libertad de los indios del regidor de Carmona, Juan Cansino Aragonés, los testigos declararon que herró a uno de ellos en la cara para poderlo vender porque de otra forma nadie lo quería comprar ${ }^{58}$. Para marcarlo por esclavo no tuvo más que ordenárselo a «uno que vive junto a la carnicerían lo cual efectuó sin demora porque el mencionado Juan Cansino no sólo era regidor, sino que pertenecía a una de las familias llegadas a Carmona tras la Reconquista y, por tanto, de las más influyentes de la localidad ${ }^{59}$.

Pese a todo no queremos dejar de mencionar la traída más excepcionalmente de algunas indias - o más usualmente mestizas - con fines benéficos o filantrópicos como podía ser enseñarles los modales de las mujeres castellanas para poder casarlas con algún español ${ }^{60}$, si bien, es cierto que en estos casos solía ocurrir que la doncella india era hija natural de los propios españoles con los que llegaba.

\section{LA LIBERTAD DE LOS INDIOS}

Como ya hemos comentado, los indios fueron trafdos injustamente a la Península, algunos en calidad de libres y la mayoría como esclavos. Ahora bien, sólo algunos de ellos tuvieron la oportunidad, o la valentía, de querellarse ante el Consejo de Indias. Pese a todo, la mayoría de los indios que litjgaron no obtuvieron fruto alguno como le ocurrió a la india Violante que se llevó toda su vida sirviendo como esclava, a distintos dueños, uno residente en Granada, otro en Huelva y finalmente otro en Cádiz, sin conseguir la liber$\operatorname{tad}$ en su juicio ${ }^{61}$.

57 Real Cédula a los oficiales de la Casa de la Contratación, Dueñas, 25 de septiembre de 1534. AGI, Indiferente General 1961, L. 3, ff. 151 v-152.

58 Pleito por la libertad de los indios de Juan Cansino, 1558. AGI, Justicia 908, N. 2. Deciaración de Juana Núñez.

59 lbidem.

60 Este justo motivo alegó Martin de Solís para traer a España a una india tlamada Catalina Bastidas. Real Cédula a los Jerónimos, Madrid, 30 de marzo de 1517. AGI, Indiferente General 419, L. 6, ff. $123-123 \mathrm{v}$.

${ }_{61}$ GIL-BERMEjo: Indigenas, ob. cit., pág. 550. Ideas, ob. cit., págs. 124-125. No es el único caso de indios que perdieron el litigio. Cuando sus propietarios eran regidores o personas de alguna manera influyente, el falto a favor del aborigen se tornaba sumamente dificil. También la india Catalina Hernández se llevó pleiteando más de treinta años con un regidor de la entonces villa de Carmona, llamado Juan Cansino, pero finalmente en 1572, debido a las poderosas influencjas de éste, fue confirmada como esclava. Pleito entre Juan Cansino y el fiscal del Consejo de Indias, 1550-1572. AGI, Justicia 908, N. I. 
No se trata de un caso excepcional el de esta india llamada Violante, pues fueron muchos los indios vendidos reiteradamente a lo largo de su vida y que por tanto se vieron obligados a cambiar de residencia varias veces en su vida. Tal vez un ejemplo que ilustra magistralmente este constante cambio de lugar y propietario sea el de un indio llamado Esteban, que describe su estancia en España de la siguiente y alucinante manera:

"Que ha treinta años que está en España y vino a ella con Pero Sancho, marinero, y le vendió a un lencero de Portugal que era portugués y lo llevóeste lencero al Reino de Portugal y este lencero vendió a este confesante a un sastre de Portugal, que se llamaba Manuel Pinto, que vivía en la ciudad de Lisboa y este sastre vendió a este confesante a un Alonso Carretero, vecino de Baeza, y este Alonso Carretero tornó a vender a este confesante al dicho Diaz Sánchez Cabrera que es con quien ahora este confesante trata pleito.... ${ }^{62}$

Normalmente estos aborígenes que se decidían a plantar cara a su propietario y reclamar su libertad eran personas que llevaban largos años residiendo en la Península, que conocían perfectamente la lengua castellana, y, que estaban bien informados de las disposiciones legales sobre la situación de su etnia.

Por otro lado, las posibilidades que tenían estos aborigenes de ganar su libertad no eran muchas ya que luchaban en franca desigualdad, dado que solían enfrentarse a personajes influyentes o al menos mínimamente situados socialmente, pues, no en vano eran los que se podían permitir el lujo de tener esclavos. En cambio, ellos con unos medios a su alcance muy limitados, es decir, con la única ayuda de un procurador de pobres, debían demostrar su condición de libres.

Ante todo nos debemos preguntar los motivos que llevaron a estos aborígenes a arriesgar su situación y a pleitear por su libertad. A nosotros no nos cabe la menor duda de que fueron los malos tratos que les proporcionaron algunos españoles lo que les llevó a luchar por su libertad. Al menos esta es la impresión que extraemos de casos como el de una india, llamada Beatriz, que con 14 años llegó a la Península en un navio negrero en el cual viajaban cuarenta indios para ser vendidos en la Península. Tras múltiples penalidades se estableció en Carmona como esclava primero de Hernán Pérez de Castroverde y luego del ya mencionado regidor de Carmona Juan Cansino. En esta localidad esta india "baja de cuerpo, delgada y con aspecto de india" procreó nada menos que a seis hijos y, transcurridos 27 años, cuando ya era una adulta, decidió pleitear contra su propietario ${ }^{63}$. Cuando le preguntaron los motivos

62 Pleito por la libertad del indio Esteban que era de Diaz Sánchez de Cabrera, vecino de Baeza, 1553-1558. AGI, Justicia 1023, N. 1, R. 1.

63 Pleito por la libertad de fa india Beatriz y de sus hijos, 1558. AGI, Justicia 908, N. 2. Los hijos se llamaban Catalina de 19 ó 20 años, Tomas de 16 años, Isabel de 14 ó 15 años, Juan de 10 ó 12 años, otra india que vivía en Sevilla, y finalmente, un indio llamado Simón que fue herrado fraudulentamente y vendido como esclavo en Sevilla.

Hispunia, LV]/3, núm. 194 (1996) 945-964 
por los que había esperado tanto tiempo para pedir su libertad respondió "porque no sabía que lo podía reclamar hasta que por cierto mal tratamiento de palos que le dio el dicho Juan Cansino, siendo informada que el Rey Su Majestad mandaba libertar a los indios vino a reclamar" ${ }^{64}$. Igualmente declaró que la causa fundamental que le impulsó a pedir su libertad era la servidumbre en que había caído su hijo Simón el cual había sido herrado en la cara y vendido por el dicho Juan Cansino ${ }^{65}$.

Pese a que, según hemos ya afirmado, eran los malos tratamientos el principal motivo por el que los indios litigaban para conseguir su libertad, lo cierto es que también se daban otras causas. En este sentido, conocemos algunos casos en los que la libertad fue solicitada tan sólo por el deseo que mostraban los indígenas por regresar a su tierra natal. Así, en el juicio por la libertad de una india de un vecino de Madrid, llamado Juan Pontiel de Salinas, ésta declaró que era cierto que la trataba muy bien pero que se quería ir a Guatemala, su tierra natal ${ }^{66}$.

En todos los pleitos consultados se ordena antes que nada que bajo ningún concepto se maltrate o se vendan los indios que litigan por su libertad ${ }^{67}$. No cabe duda de que la situación, como es de suponer, era bastante difícil para aquellos naturales que decidían pleitear por su libertad, ya que desde el mismo momento en que los propietarios detectaban tal intención, intentaban disuadirles, bien, a través de malos tratos y amenazas, o bien, consiguiendo una rápida venta. Asi, por ejemplo, un indio llamado Tomás cuando decidió pedir su libertad, en la misma carta incluyó una segunda petición que decía así:

"Otrosí, pido y suplico a Vuestra Alteza me mande poner en una parte segura porque yo no vuelva a poder del dicho Ambrosio Rotulo porque temo que me matará o me maltratará o cuando otro lugar me haya Vuestra Alteza mande se me quiten las prisiones y que dé fianzas que no me maltratará ni me transportarán 68 .

64 lbidem. La falta de conocimiento o la ignorancia es una de las razones frecuentemente aludidas por los indios cuando se les preguntaba por qué motivo no la habian solicitado antes. Así, un indjo llamado Sancho que pleiteó por su libertad, en 1554 declaró «Que por las Leyes Nuevas era libre y antes no me declaré sino por ignorancia...». Pleito entre Sancho, indio, y Gaspar Pérez, vecino de Salamanca por su libertad, 1554. AGI, Justicia 1022, N. 3, R. 2.

65 Curiosamente, la india aducía que su hijo fue herrado sin problemas por Juan Cansino porque «era regidor y favorecido en la dicha villa de Carmona». Ibidem.

${ }_{66}$ En concreto en este pleito se dijo que la trataban «como a jubilada y que no hacía ni hace más de lo que ella quería y cuando ella quiere servir sirve y cuando no está en la caman. Preguntada la india por qué motivo pedía su libertad respondió que porque se queria ir «de buena gana a la provincia de Guatemalas. Pleito por la libertad de la india Catalina esclava de Juan Pontiel de Salinas, 1552. AGI, Justicia 1021, N. 3, R. 1.

67 Véase AGI, Justicia 1022 donde hay varios pleitos por la libertad de ciertos indios algunos de ellos ya citados en notas anteriores.

68 Pleito por la libertad del indio Tomás frente a Su propietario Ambrosio Rótulo, 1563. AGI, Justicia 1025, N. 2, R. 2. 
Pese a todo fue difícil protegerlos de sus amos como lo demuestra el caso de un indio, llamado Juan, que cuando fue declarado libre, su antiguo propietario, un granadino llamado Martín de Prado, amenazó tan seriamente al indio que éste escribió al Consejo de Indias diciendo que "lo quería echar a galeras su amo y a todos los indios que tomare» ${ }^{69}$. Incluso, conocemos casos en los que los antiguos propietarios llegaron a pegar y a maltratar a estos indefensos indios cuando se enteraron de su intención de pedir su libertad, como ocurrió con indio de Gonzalo de Salazar, llamado Martín ${ }^{70}$.

$\mathrm{Y}$, finalmente el caso, también muy interesante, de otro indio que intentaba escaparse de la injusta esclavitud que le quería imponer su "propietaria", doña Inés Carrillo, al optar ésta por colocarle uuna argolla de hierro al pescuezo esculpidas en ellas unas letras que dicen esclavo de Inés Carrillo, vecina de Sevilla a la Cestería" "1. La propietaria Inés Carrillo tuvo todavía el atrevimiento de afirmar que lo trataba como si fuera su hijo, logrando, gracias a sus buenas influencias, que el indios fuese declarado, definitivamente, como esclavo.

No obstante, debemos decir que este deseo de los propietarios de evitar su libertad eran hasta cierto punto lógicos, dado que no sólo perdían un esclavo, que en su mayor parte habian comprado legalmente en el mercado de esclavos a comerciantes españoles o lusos, sino que además debían pagar los costes del pleito. Incluso, como ya hemos visto, en algunas sentencias se vieron obligados a indemnizar al indio por los años que le había servido normalmente a razón de diez o doce pesos de oro anuales. Es evidente que el pequeño propietario se veía injustamente perjudicado pues no debemos perder de vista que solían tener los documentos de sus esclavo en regla. La mayoría de los españoles implicados en los pleitos presentaban dos pruebas que creian suficientes para demostrar la servidumbre de sus indios, a saber: la

69 Se hizo una pequeña pesquisa y los testigos fueron unánimes en sus declaraciones. En particular el portero de la Casa de la Contratación Diego Coltantes declaró que cuando dieron al indio por libre oyó decir a Martín de Prado «que juraba a Dios que todos cuantos indios pudiese haber en esta ciudad de dar con ellos en galeras y que después de esto desde a cierto rato tornó a decir que todos los que él comprase...». AGI, Justicia 741, N. 3.

70 En concreto en el pleito por la libertad de un indio, propiedad de Gonzalo de Salazar, el desgraciado abotigen declaró lo siguiente: «Otrosí digo que porque ayer parecía en este Vuestro Consejo Real de las Indias y proclamé en libertad el dicho factor Salazar me amenazó que me habia de herir y hacer malos tratamientos y luego lo comenzó a poner en obra y me dio muchos golpes y cabezazos en una pared y sino fuera porque unos hombres y mujeres me quitaron me matara. Según es hombre severo y cruel temo me matará como lo ha comenzado, pido y suplico a Vuestra Alteza luego me mande sacar de su poder y poner en parte segura do no me maltrate hasta que la causa sea determinada». Pleito por la libertad del indio Martín, propiedad de Gonzalo de Salazar, 1539. AGI, Justicia 1007, N. 1, R. 1.

71 Declaración del médico Cristóbal de Hojeda en el pleito por la libertad del indio Diego, que sirve por esclavo a Inés Carrillo, 1534. AGI, Justicia 716, N. 4. En realidad se trataba de una practica muy empleada con los esclavos negros a los cuales se le solia marcar en la cara o poner esta argolla en el cuello con el nombre de su propietario.

Hispania, LVL/3, núm. 194 (1996) 945-964 
carta de compra del indio, y, en la mayoría de las ocasiones, la marca - ejecutada con el hierro real - que presentaban los aborígenes en el rostro o en la pierna. Según los españoles el hierro era suficiente para demostrar su servidumbre pues uestando herrados en el rostro con el hierro de Su Majestad sólo bastaba por título porque así se había usado y acostumbrado después que esas partes se descubrieron" 72 .

Lo cierto es que el hierro no fue considerado como prueba ya que los propios jueces fueron conscientes de que se habían herrado multitud de indios irregularmente no sólo en América sino en la propia península. Sin embargo, la carta de compra sí que demostraba la inocencia del español al haberlo adquirido legalmente mediante una típica operación de compraventa. En realidad, el responsable último era el comerciante de Indias que había traído fraudulentamente al indio, violando la legislación vigente.

Sin embargo, la justicia real nunca fue contra ellos, ni siquiera en aquellos casos en los que se descubrió la ilegalidad en plena venta, en cuyo caso tan sólo perdían esas piezas concretas sin ningún tipo de castigo añadido. La razón de este anormal comportamiento lo hemos justificado en el hecho de la gran alianza formada entre los grandes comerciantes y la Corona, al ser éstos sus principales aliados y a los que, como es sabido, la Corona recurría cada vez que se encontraba en apuros financieros.

Cuando el pleito se ponía en marcha, sin que el propietario hubiese podido disuadir al indio, la estrategia era siempre la misma. Primero, presentaban la carta de venta alegando ser documento suficiente para la legítima posesión del esclavo. Y segundo, intentaban demostrar siempre una procedencia brasileña con la intención de que el aborigen en cuestión quedara fuera de la legislación protectora del indio de los reinos de Castilla ${ }^{73}$. Así, por citar un ejemplo representativo, en el pleito por la libertad de un indio llamado Pedro, los testigos declararon que era de buena guerra de Portugal porque «cuando le preguntaban si creía en Dios él decía que sí que creía en Dios de Portugal de manera que él es fino portugués..." ${ }^{74}$, sin embargo, posteriormente, se demostró que los testigos habían sido comprados y que en realidad era originario de la Nueva España.

En muchas ocasiones encontramos que los propietarios habían amenazado antes del juicio a los propios indigenas para que afirmasen que procedían del Brasil. En concreto en un pleito por la libertad de un indio llamado Martín Quintín, testigos, que no demostraron un especial favor hacia los indios, reconocieron que el indio mentía cuando decía que era originario de tierras coloniales portuguesas. Así, por ejemplo, Juan Barba de Vallecillo declaró lo siguiente:

72 Pleito por la libertad de la india Maria, propiedad de Costne de Mandujana, estante en la Corte de Madrid, 1566. AGI, Justicia 1025, N. 5, R. 2.

73 En 1550 la Corona declaró libres a los indios del Brasil que estuviesen en las indias Espanolas. Valladolid, 7 de julio de 1550 . Recopilación, T. II, Lib. VI, Tit, II, Ley V.

74 Pleito entre Pedro indio y el licenciado Flores. AGl, Justicia 1022, N 5, R 1. 
"Que el indio que le enseñaron a este testigo eneste real Consejo como dicho tiene le parece a este testigo que por su gesto y habla y por las señas es indio natural de las Indias pero que nosabe este testigo de qué parte más de que el dicho indio decía que era del Brasil pero que a algunas palabras que este testigo le habló e hizo que le hablase en lengua mexicana parecía que entendía algo aunque no se declaraba el indio porque parecía estar atemorizado" ${ }^{75}$.

Otros, intentaban demostrar que eran caribes, muy ingenuamente, porque la Corona hacía décadas que había aprendido que la palabra caribe se utilizaba siempre como excusa para esclavizar fraudulentamente. Incluso en uno de estos pleitos se afirmó sobre una india esclavizada fraudulentamente que "no era india sino árabe hija de moro», idea que desde luego no fue tomada en consideración por los letrados que instruían el caso ${ }^{76}$. Cuando el tribunal llegaba finalmente a la conclusión de que el indio en cuestión era originario de la América española la situación se tornaba mucho más favorable para éste, ya que, como es sabido, en principio y al menos desde las Leyes Nuevas de 1542 todos los indios de las colonias españoles eran legalmente personas libres ${ }^{77}$.

En algunas ocasiones algunos españoles intentaban una acción desesperada para evitar pagar las costas del pleito o la indemnización. En este sentido sabemos que, en 1553, un vecino de la ciudad de Salamanca, llamado Antonio de Herrera, liberó a su india con la intención - no declarada por supuesto- de evitar la indemnización e incluso de conseguir que ésta le siguiese sirviendo por un reducido salario ${ }^{78}$.

En el supuesto de conseguir su libertad, el indio se enfrentaba a otra serie de problemas de muy complicada solución. En primer lugar, y como ya hemos mencionado, los españoles no siempre aceptaban su derrota, hasta el punto de que en muchas ocasiones el Rey debía insistir a la Audiencia para que velasen por el cumplimiento de la sentencia. Concretamente, en el caso de un indio del Capitán Martín de Prado que fue declarado libre el Rey debió escribir a la Audiencia para que lo compeliesen a ponerlo en libertad, pues pese a la sentencia no lo había querido hacer ${ }^{79}$.

75 Pleito por la libertad de Martín Quintín, 1559. AGl, Justicia 1023, N. 2, R. 3.

76 Pleito por la libertad de los indios de Juan Cansino, 1558. AGI, Justicia 908, N. 2, f. 14v.

77 En un pleito por la libertad de un indio propiedad de un vecino de Baeza llamado Dia Sánchez de cabrera, intervino el propio Obispo de Chiapas fray Bartolomé de las Casas como testigo. Este, que en esta declaración, tomada en 1558 , declaró ser de edad de «más de cincuenta años» preguntado por la libertad de los indios de la Nueva España responđió con la contundencia que le caracterizaba: «Que sabe la dicha pregunta como en ella se contiene porque por tales como la pregunta dice libres, y de su nacimiento, tiene este testigo a todos los indios contenidos en las provincias de la dicha pregunta y asi Su Majestad lo ha mandado poner en libertad a los dichos indios y que el dicho Esteban es tan libre como este testigo y por esto lo saben. Pleito por la libertad del indio Esteban, 1553-1558. AGI, Justicia 1023, N. 1, R. 1.

78 Pleito por la libertad de la india Beatriz, 1560. AGl, Justicia 1024, N. 3.

79 Real Cédula a Juan Gutiérrez Calderón, escribano de la Audiencia, Valladolid 31 de mayo de 1544. AGI, Indiferente General 1963, L. 9, f. 83v.

Hispania, LVI/3, núm. 194 (1996) 945-964 
En segundo lugar estaba el asunto de su mantenimiento mientras estuviese en Castilla a la espera de embarcarse, y del pago de su pasaje para las Indias. La Corona evitó durante décadas el tener que hacerse cargo de estos costes de forma oficial, aunque casi siempre aceptó el pago de aquellos pasajes que los indios liberados le solicitaron. Así, por ejemplo, en 1540, la Corona ordenó que se le pagase el pasaje de vuelta a México a un hijo de Moctezuma, llamado don Pedro, y a otro indio principal llamado don Gabriel ${ }^{30}$. Igualmente, en 1549 , se ordenó a los oficiales de la Casa de la Contratación que pagasen el pasaje a un indio guatemalteco, llamado Francisco, que volvía a su tierra natal con su mujer y con su hija pequeña ${ }^{81}$. E incluso, en alguna rara ocasión se le pagó el pasaje a un grupo de indios, como ocurrió en 1543, en el que en el mismo momento de su llegada se ordenó su regreso inmediato en la flota que salía para las Indias, dado que para esta fecha estaba totalmente prohibida su traída desde las Indias españolas ${ }^{82}$.

Hacia 1551, el Rey se sintió en la obligación de ordenar a los oficiales de la Casa de la Contratación que pagasen los pasajes de todos los aborígenes que quisiesen volverse a las Indias porque "por ser pobres no tienen medios para volverse a sus tierras» ${ }^{83}$.

En otras contadas ocasiones el viaje se financiaba a través de la indemnización que los españoles debían abonar a los indios que conseguían su libertad. Sin embargo, esta solución apenas sirvió durante unos años ya que a partir de la década de los cincuenta cada vez fueron menos frecuentes estas indemnizaciones. Así, por ejemplo, en 1558 se resolvió favorablemente sobre la libertad de un indio llamado Juan, propiedad de Juan de Hernán Carrillo Rótulo, pero, en cambio, fue absuelto del pago al considerarse muy gravoso para su economía ${ }^{84}$

En cualquier caso, lo cierto es que la mayoría nunca contó con los medios suficientes como para volver a la tierra que les vio nacer, de forma que, aun despues de haber perdido el pleito, los antiguos propietarios siguieron aprovechándose de los aborígenes. En este sentido conocemos el caso de un indio llamado Juan de Oliveros, que tras ser declarado libre, en 1549, su antigua propietaria María Ochoa de Vizcarra le azotó hasta que consiguió que el desgraciado indio firmara una carta ante notario en la que se concertaban para servirla por cínco años a cambio de manutención ${ }^{85}$.

${ }^{80}$ Real Cédula a los oficiales de la Casa de la Contratación de Sevilla, Madrid 22 de noviembre de 1540. AGI, Indiferente General 1963, L, 7, ff, 219v-220.

81 Real Cédula a los oficiales de la Casa de la Contratación, Valladolid, 21 de julio de 1549. AGI, Indiferente General 1964, L. 11, ff. 260-260v.

82 Real Cédula a los oficiales de Sevilla, valladolid 21 de septiembre de 1543. AGI, Indiferente General 1963, L. 8, f. 259.

83 Real Cédula a los oficiales de la Casa de la Contratación, Vallađolid, 25 de noviembre de 1552. Recopilación, T. II, Lib. VI, Tit. I, Ley XVII, f. 190.

84 Pleito por la libertad del indio Juan, Valladolid, 28 de mayo de 1558. AGI, Escribania 952, f. 85.

85 La carta de concierto se formalizó ante el escribano público de Sevilla Andrés de Toledo el 3 de junio de 1550 . Pleito por la libertad de Juan de Oliveros y Beatriz, indios de María Ochoa de Vizcarra. AGI, Justicia 757, N. 3. 
Por supuesto, los indios que no consiguieron su libertad lo tuvieron aún más difícil para volver entre otras cosas porque estaba prohibido que los indios esclavos retornasen al Nuevo Mundo sin expresa licencia real pese a que contase con la autorización de su dueño. Debido a algunas quejas que a este respecto el Rey expidió una Real Cédula, en 1540, en la que ordenó a sus oficiales de la Casa de la Contratación que dejasen volver a los esclavos indios siempre que fuese de su propia voluntad y contasen además con una autorización de sus propietarios ${ }^{86}$. Sin embargo, poco efecto debió surtir esta Real Cédula pues unos años después conocemos el caso de una esclava india que quería volver, con permiso de su propietaria, a La Habana y las autoridades no se lo consintieron hasta que contó con una licencia real expresa ${ }^{87}$.

No queremos finalizar este epigrafe sin citar al menos el hecho de que, al igual que los esclavos negros, algunos indios fueron liberados por voluntad de su amo. En este sentido conocemos dos caso, uno, fechado en 1508, en que un vecino de Sevilla, llamado Pedro de Tudela de Duero, liberó a un indio suyo, natural de La Espańola, y otro caso similar, al año siguiente, cuando el mercader florentín, afincado igualmente en Sevilla, Simón Verde, ahorró a un indio y cuatro negros ${ }^{88}$. En realidad la situación del indio horro apenas variaba ni a nivel social ni por supuesto económico ya que lo normal es que continuasen sirviendo en las mismas condiciones a sus antiguos propietarios. Precisamente esta condición quedó especificada en la carta de libertad otorgada por el ya citado Pedro de Tudela de Duero para liberar a su indio, pues, se señaló «indio ahorrado, pasa a ser su criado" ${ }^{89}$.

En cualquier caso lo que debe quedar claro es que las situaciones conflictivas son las que generaron documentos tales como un pleito, mientras que la buena convivencia entre esclavos y propietarios apenas nos ha quedado registrada para la historia. Por ello, no podemos perder de vista que debio haber muchos españoles que proporcionaron buenos tratamientos a sus indios y a sus negros, ahorrándolos en muchos casos al final de sus vidas.

${ }^{86}$ Real Cédula a los oficiales de la Casa de la Contratación de Sevilla, Madrid 29 de noviembre de 1540. AGI, Indiferente General [963, L. 7, ff 221 v-224.

87 Real Cédula a los oficiales de la Casa de la Contratación, Madrid 13 de enero de 1546. AGI, Indiferente General 1963, L. 9, ff. 318-318v.

* Franco Silva, Alfonso: Regesto documental sobre la esclavitud sevillana (1493-15/3). Sevilla, Servicio de Publicaciones de la Universidad de Sevitla, 1979, S/P.

\$9 lbidem.

Hispania, LV1/3, nửm. 194 (1996) 945-964 